\title{
ONCE TESIS PARA UNA TEORÍA MATERIALISTA DE LA FOTOGRAFÍA. Y CUATRO APROXIMACIONES METODOLÓGICAS
}

\author{
Pablo Huerga Melcón \\ IES Rosario de Acuña, Gijón
}

Resumen.- Este ensayo ofrece una serie de once tesis que podrían contribuir a la elaboración de una teoría filosófica materialista de la fotografía. La primera parte fue escrita en el año 2007, mientras que las consideraciones metodológicas son inéditas, y complementan y aclaran algunas de las cuestiones que resultaron particularmente difíciles a los lectores. El texto de 2007 aparece sin modificaciones, para preservar el propio desarrollo cronológico de la teoría.

\section{Primera parte: Once tesis para una teoría materialista de la fotografía}

\section{Introducción}

La fotografía es un fenómeno nuevo en la historia, un acontecimiento tecnológico del siglo XIX. Su nacimiento se hace posible en virtud del desarrollo de las investigaciones en Física, Química, Óptica y Geometría. Por primera vez en la historia, permitió fijar en un plano una imagen circunstanciada, situada en un momento del espacio y del tiempo: "detener el movimiento"; alcanzar lo que con las representaciones pictóricas se había venido haciendo de manera artesanal y laboriosa, desde la época de las cavernas. De hecho, las imágenes nacen con el Hombre de Cromagnon, no las hay aún, según parece, con los Neandertales. Los hombres de Altamira fijaban en el cielo de las cavernas las figuras de los animales que cazaban, en pleno movimiento, hacían reproducciones en negativo de sus propias manos. En muchas ocasiones, se secuencian las imágenes para representar el movimiento de los animales, o de los hombres. En el palacio de Asurbanipal, en Nínive, encontramos entre otros, el famoso relieve de la caza de los leones: primero, el rey en carro disparando la lanza; después, el león moribundo con la lanza clavada; más adelante, el león transportado en el carro por sus sirvientes, y el rey orgulloso volviendo al palacio. Una escena de este tipo puede apreciarse ya en una espada micénica de hace 3600 años, donde se representa también una caza de leones. Por los relieves de las escaleras del palacio de Persépolis se muestran los distintos pueblos sometidos al imperio haciendo ofrendas a su rey, etc. En la Acrópolis de Atenas un viajero podía contemplar paso a paso la procesión de las Panateneas, con solo circunvalar el Partenón. En el relieve más extenso de la antigüedad, la columna de Trajano, se representa en espiral la conquista de la Dacia, etc. 


\section{El Mito de la caverna}

El poder de las imágenes ha sido tan evidente desde el nacimiento de la cultura occidental que Platón llegó a sintetizar una estructura: el Mito de la caverna, en donde las imágenes, fruto de la proyección de sombras en la pared que tenían delante, mantenían a los esclavos convencidos de que aquello era la realidad. La liberación de los esclavos consistía, entre otras muchas cosas, en comprender cómo se producían aquellas imágenes, conocer la causa eficiente que daba lugar a aquellas sombras, y entender así la diferencia entre apariencia y realidad.

Esta enorme metáfora extiende sus sombras hasta nuestros días, donde el mito de la caverna se renueva a cada instante, piénsese en La caverna de José Saramago, o en el libro de Gustavo Bueno, La vuelta a la caverna, etc.; y es natural, porque nuestro mundo ha quedado, por así decir, absorbido en la propia representación que hemos ido creando de él. Es como si de pronto, el escenario del teatro griego hubiera sido transformado en un espejo, en el que ahora los espectadores se ven a sí mismos reflejados, actuando ahora ya con el papel de espectadores. Conjuramos el mito de la caverna cuando en vez de una pantalla sobre la que se reflejan sombras, colocamos un espejo en el que se ven a sí mismos los prisioneros. En gran medida, nuestra obsesión por las imágenes nos ha instalado en un escenario sin fin en el que los espectadores absolutos han desaparecido, mientras que todos permanecemos al acecho de las sombras, fisgando a los demás, con una constante sensación de que nuestra propia vida es un guión televisado, y formando parte siempre del fondo de escena sobre el que se representa la vida de los demás.

El teatro griego cultivó ese ejercicio de representación, que reproducía como reflejo de las narraciones de los mitos, o de acontecimientos perdidos en la niebla de los tiempos, historias aparentes. Pero estas historias, al igual que las imágenes para los esclavos, tienen una enorme fuerza en quien las ve. Los espectadores del teatro sufrían viendo a sus personajes padecer, y se compadecían de ellos.

El éxito del teatro, como dice Aristóteles, consiste en arrebatar al espectador, y sacarle de su sano empirismo para hacerle vivir, y no sólo ver, lo que se está representando delante de él: "[...] la obra debe estar compuesta de tal modo que, aun sin verlos, el que escucha el relato de los hechos se estremezca y sienta compasión por lo que ocurre, que es la sensación que experimenta el que escucha el relato del destino de Edipo" ${ }^{\text {. }}$. Por cierto, Aristóteles considera la imitación como algo "connatural" al hombre, y el ser apto para la imitación es lo que lo diferencia de los demás animales, "[...] y es que nos complacemos en la contemplación de las imágenes, porque, al mirarlas, se aprende en ellas y de ellas se deduce lo que cada cosa representa: por ejemplo, que esta figura es tal cosa" ${ }^{2}$. Esas imágenes tienen un efecto purificador en el público, y le

\footnotetext{
${ }^{1}$ Aristóteles, Poética, XIV

${ }^{2}$ Aristóteles, Op. Cit., IV
} 
ayudan a retomar su vida y replantearse su conducta, representársela tal y como la ven reflejada en el teatro: "[...] imitación que se efectúa con personajes que obran, y no narrativamente, y que, con el recurso a la piedad y el terror, logra la expurgación de tales pasiones". Las imágenes crean movimientos en el alma, dice Platón, y logran pasar por el filtro de la razón y el entendimiento para afectarnos más allá de la realidad. Los griegos cultivaban, además, un arte extraordinariamente extendido y cotidiano: las vasijas ilustradas, en las que podemos encontrar representados desde acontecimientos domésticos, escenas mitológicas, personajes conocidos, relaciones sexuales, etc. Curiosamente, estas imágenes se hacen normalmente en "rojo y negro".

\section{Reproducir la realidad}

Ha habido siempre un esfuerzo decidido por reproducir la realidad, por acercarse a ella al máximo, por imitarla, tal y como dice Aristóteles. En la época helenística encontramos un caso característico y especialmente llamativo: el de los retratos de la necrópolis de El Fayum en Egipto, conocidos ya desde el siglo XVII. Sobre momias adornadas se insertan mediante un proceso parecido al del fotomontaje retratos en madera de rostros con una individualidad extraordinaria. Llama poderosamente la atención el esfuerzo por dejar fijados en aquellos sarcófagos el rostro vivo del muerto o de la muerta, con todo detalle, pero también llama poderosamente la atención el extraordinario parecido que tienen esos rostros con los nuestros. Es un curioso ejercicio buscar parecidos entre esos personajes y personas concretas que viven entre nosotros. El caso es que en el viaje al mundo de Osiris era esencial ser identificado correctamente, por eso seguramente esos rostros procuran ser tan precisos e individuales. De los romanos se dice que fueron los inventores del retrato hecho con fidelidad al original, y de ello dan cuenta multitud de ejemplos. Los extraordinarios mosaicos romanos, en ocasiones, actuaban como reflejo de las propias actividades desarrolladas en los recintos donde se encontraban, etc.

Con la implantación definitiva del cristianismo estas costumbres desaparecen, aunque el cristianismo utilizará sistemáticamente las imágenes con fines propagandísticos, divulgativos y educativos, y en su seno nacerá un cisma producido por la polémica de las imágenes y su relación con la realidad representada, que dará lugar a la primera separación de la Iglesia entre Roma y Constantinopla. El Islám, por otra parte, renuncia expresamente a cualquier tipo de representación pictórica, y aun hoy la imagen es para ellos "algo" más que una imagen; le conceden un poder mágico sobre la realidad representada, una especie de desafío al destino (podemos recordar el asunto de las caricaturas de Mahoma, y el revuelo verdaderamente desproporcionado que suscitaron).

El escolasticismo, como sugiere Le Goff, sigue adelante con la teoría antigua del arte como imitación de la naturaleza. Juan de Meung decía: "El arte no produce formas tan verdaderas. De rodillas ante la naturaleza muy atento le ruega y le suplica (como un mendigo y un truhán escaso de ciencia y de poder, pero preocupado por imitarla) que le enseñe a abrazar la realidad en sus 
figuras. El arte observa cómo trabaja la naturaleza pues bien quisiera hacer una obra semejante y la imita como un mono, sólo que su débil genio no puede crear cosas vivas por simples que parezcan."3 Este naturalismo tiene sus consecuencias posteriormente para el desarrollo de la ciencia, como se puede comprobar en la figura de Vesalio, por ejemplo. Con él se recupera el arte de la disección en la práctica médica, como recuerda Farrington, y una de las peculiaridades que ofrece es precisamente la representación visual de sus estudios anatómicos, tal como aparecen en De humani corporis fabrica.

\section{De la pintura a la fotografía pasando por la pintura de la fotografía}

En el libro, El conocimiento secreto, David Hockney ${ }^{4}$ revela que el surgimiento del realismo de los maestros flamencos se debió al uso de espejos y lentes para copiar con precisión "casi fotográfica" las imágenes reflejadas. Vermeer, Caravaggio, Leonardo, Velázquez, Rembrandt, Van Eyck, Holbein o Hals, utilizaron estas técnicas, que sin embargo se mantenían en secreto. Con estas técnicas los pintores aspiraban a realizar una especie de "instantáneas al óleo" basadas en composiciones de escenas previamente preparadas, y no sobre estudios gráficos previos. Este autor, también advierte que, paradójicamente, con la invención de la fotografía a mediados del siglo XIX, los pintores se alejarán del realismo abriéndose a horizontes totalmente nuevos que seguirán dando sentido a su arte, frente a esa incesante búsqueda de recreación de la realidad en la imagen.

Este nuevo viaje de la pintura, sin embargo, tiene su contrapunto en el intento de emular con el cuadro la propia fotografía, no sólo en el llamado hiperrealismo, sino en actitudes mucho más sutiles, como la del cuadro de Picasso, El Guernica, hecho en formato cinemascope, en blanco y negro, y con todas las connotaciones de un acontecimiento captado por la cámara. Siempre he creído, fuera del sentir de los críticos de arte y los grandes comentaristas de esta obra, que El Guernica hay que leerlo en esta clave. Este cuadro recrea la imagen de la Sagrada Familia en la escena del portal de Belén, rota por el estallido de las bombas, la Virgen con su hijo muerto, San José agonizante, descuartizado, empuñando una espada rota, el toro y el caballo (mula y buey sexuados), los ángeles que anuncian la muerte, y no el nacimiento, la luz de los estallidos que entran de pronto por la puerta iluminando la escena.

La escena es ante todo un fogonazo, un flash captado por la cámara, y proporcionado por el estallido de las bombas. Tras ese flash, lo que queda recogido en el negativo es esa escena nocturna de muerte y destrucción, en blanco y negro, como se hacían las fotos entonces, emulando la labor de los fotógrafos de guerra que comenzaron su profesión precisamente en nuestra Guerra Civil (sin embargo, es cierto que ya hay registros fotográficos de la guerra de Crimea). Picasso quiso estar en Guernica y hacer esa fotografía que reproduce el dolor de la "sociedad civil" encarnada en esa familia sagrada,

\footnotetext{
${ }^{3}$ Le Goff, Los intelectuales en la edad media, Gedisa, Barcelona 1986; pág. 105

${ }^{4}$ David Hockney, El conocimiento secreto, Destino, Madrid 2001.
} 
símbolo de la tragedia, y del exilio de los refugiados. Precisamente la sociedad civil como tal es un invento del cristianismo en el proceso de formación contra el Estado romano, y por eso, el sufrimiento de la población civil, como táctica militar, que comienza a utilizarse sistemáticamente en la Guerra Civil española, no puede quedar mejor representado que en el modelo de la Sagrada Familia. El cuadro, sin duda, lo sugiere, no lo afirma, pero para la sociedad católica española es suficiente ${ }^{5}$.

Pero todos esos esfuerzos por reproducir en la imagen la realidad tal como es resultaron baldíos hasta la aparición de la fotografía, porque no se trata solamente de que con la invención de la fotografía podamos hacer una reproducción más precisa, emulando las tendencias naturalistas de los pintores, ni de hacer retratos tan parecidos al original ("con precisión casi fotográfica"). Porque, mayormente, la fotografía, en sus inicios, era en blanco y negro $\mathrm{y}$, aunque las formas fueran muy correctas, el color dejaba mucho que desear. Por otra parte, como recuerda Gustavo Bueno, Pierre Francastel sostenía en su obra Pintura y sociedad (1952), que la cámara fotográfica nació como aparato para producir imágenes en perspectiva pictórica. De hecho, Daguerre y Talbot fueron pintores (aunque Nièpce era científico e inventor). Las primeras fotografías parecían pinturas. Y es que desde un primer momento se intentó hacer arte pictórico con ellas y, ciertamente, no ha dejado de hacerse: por ejemplo, podemos recordar el Fotocollage (1935), de Nicolás de Lecuona, o No robarás (1934), de Joseph Renau, o las actuales composiciones de Ouka Lele, etc.

Pero, la cuestión que se suscita con la aparición de esta nueva tecnología no es la de alcanzar un fiel reflejo del modelo, que eso ya lo habían conseguido, sin duda con mucho más éxito, los pintores clásicos; la cuestión es hacerlo de manera instantánea, en un proceso automático en el que el modelo no necesita prácticamente ni mantener la compostura, sólo tal vez un pequeño instante. En efecto, aunque al principio la máquina de Daguerre y Nièpce suponía varios minutos de exposición, lo cierto es que ya en "1843 el tiempo de exposición oscilaba entre un segundo y dos minutos, según la luz y el formato de las placas de cobre. Fue entonces -dice Publio López Mondéjar-, cuando el retrato daguerrotípico se impuso definitivamente y cientos de fotógrafos siguieron los pasos de Robert Cornelius y Richard Bearn, quienes en 1840 y 1841 abrieron los primeros estudios profesionales en Filadelfia y Londres, respectivamente"6. Otro detalle: el negativo puede positivarse automáticamente de manera indefinida.

Por otra parte, también es cierto que el invento fue presentado el día 7 de enero de 1839 por el astrónomo François Arago en la Academia de las Ciencias de París, no en una institución dedicada al arte pictórico; lo cual

\footnotetext{
${ }^{5}$ Véase nuestro ensayo, "La otra cara del Guernica", en Nómadas. Revista Crítica de Ciencias Sociales $\quad y \quad$ Jurídicas, $23 \quad$ (2009.3) (http://redalyc.uaemex.mx/src/inicio/ArtPdfRed.jsp?iCve=18111418006).

${ }^{6}$ Publio López Mondéjar, Historia de la fotografía en España. Fotografía y sociedad desde sus orígenes hasta el siglo XXI, Lubwerg eds., Madrid 2005; pág. 20.
} 
permite hacerse una idea de cómo concebían ellos mismos su invento: más como un aparato científico que artístico.

Un simple acto técnico, mediante la máquina fotográfica, y todo surge necesariamente en virtud de los procesos químicos establecidos. No hay reconstrucción, no hay composición, la reproducción no da lugar a modificaciones en la composición de la imagen. Nace lo que podemos llamar la fotografía en sentido formal, frente a esas reproducciones anteriores, que son fotográficas, solamente, en sentido material. Fotografías en este sentido formal, magistrales, pueden citarse infinidad de ellas, pero podríamos recordar, por ejemplo, Neutral Corner (1961), de Ramón Masats, Despedida de emigrantes (1956), de Manuel Ferrol, Miliciano abatido en el cerro Muriano (1937), de Robert Capa, Mercado del Born (1962), de Xavier Miserachs, etcétera, etcétera.

\section{Teoría materialista de la fotografía}

La teoría materialista de la fotografía deberá empezar por establecer una distinción entre estas dos nociones de fotografía: la fotografía formal, o verdadera fotografía, y la fotografía material, o falsa fotografía. La fotografía formal es aquella que, hecha por medio de la máquina fotográfica, nos ofrece la composición de formas tal y como han sido captadas por el objetivo, sin manipulaciones anteriores o posteriores. $Y$ no nos referimos a manipulaciones, por ejemplo, de coloración del fotograma, sino de manipulaciones que cambian la disposición de las formas, o las sustituyen, o las cortan, etcétera, o de manipulaciones que hacen una composición forzada de la imagen. Y será fotografía material toda imagen fotográfica que haya sido resultado de una manipulación de las formas, por eliminación, por recorte, etcétera. No podemos discutir aquí otras distinciones ensayadas por otros autores, como la que distingue la imagen periodística de la imagen de ficción, o la fotografía verdadera frente a la fotografía no verdadera, etc. Nos parece, en general, que nuestra clasificación y nuestra definición tiene mucha más capacidad de organización y análisis, en relación, particularmente, con el asunto de la Verdad. Hemos utilizado la noción de fotografía material y formal trasladando a la fotografía las nociones de televisión formal y material que ofrece Gustavo Bueno en su libro, Televisión, apariencia y verdad ${ }^{7}$.

Un caso típico de fotografía material sería todo el conjunto de aquellas célebres manipulaciones denunciadas una y otra vez por los críticos de la URSS en donde se habría conseguido, mediante procesos de montaje, la eliminación de figuras cuya presencia era inconveniente. Es famosa la fotografía de Lenin dando un discurso ante el teatro Bolshoi de Moscú. En ella, aparece también Trotski situado en las escaleras que subían al estrado. Sin embargo, en las reproducciones de la época, Trotski desaparece sin dejar rastro. Kirov, Kamenev, Zinoviev, Bujarin, y otros muchos dirigentes políticos, fueron objeto de diversas manipulaciones.

\footnotetext{
${ }^{7}$ Gustavo Bueno, Televisión: apariencia y verdad, Gedisa, Barcelona 2000.
} 
Desgraciadamente, estas prácticas han permitido a veces a los críticos de la URSS infravalorar injustamente acontecimientos históricos de extraordinaria trascendencia llevados a cabo por la URSS, haciendo hincapié en la sospecha de que todo está "amañado", como cuando se pone en duda la "formalidad" de una imagen como la fotografía de Yevgueni A. Chaldej, Soldado soviético izando la bandera roja sobre las ruinas del Reichstag, (2 de mayo de 1945). En esta fotografía queda patente la victoria total del Ejército Rojo en la decisiva Batalla de Berlín. Toda la miseria interpretativa se ceba en la supuesta desaparición de un reloj de pulsera, en la exigua presencia de humo, o en que la bandera no era "original", sino cosida para la ocasión, pero ¿acaso desmiente eso lo que la imagen está describiendo, esto es, la derrota total del nazismo por parte del Ejército Rojo? Pero la digitalización de la información, de la imagen, y la intencionalidad de los intérpretes puede dar lugar a todo tipo de abusos. En este sentido, el macabro temor denunciado por Orwell en la novela 1984, derivado de la posibilidad efectiva de reescribir la historia, hoy, gracias a la digitalización y multiplicación de las imágenes, es una realidad ante la que estamos cada vez más indefensos, salvo que asumamos la destrucción mediática de la Verdad, sin excepciones.

La razón por la que se practica la manipulación no explícita está precisamente en el valor de verdad de la fotografía en sentido formal. Si conseguimos una manipulación que apoyándose en la confianza del espectador, genere una emoción o una idea que nos interesa, dando a entender que realmente se trata de una fotografía "original", esto es: formal, habremos conseguido nuestro objetivo. La manipulación de la fotografía de Ostwall, o la denuncia de Stephen Jay Gould sobre la manipulación de las fotografías en las que aparecen deficientes mentales, con el fin de que su aspecto resulte más siniestro, en el libro del eugenista Henri Gooddard, The Kallikak Family: A Study in the Heredity of Feeble-Mindedness (1912), son ejemplos de lo que estamos diciendo ${ }^{8}$. El montaje tiene sentido precisamente por cuanto se oculta bajo la fuerza persuasiva de verdad de la fotografía entendida como fotografía formal.

Pero, en general, esta distinción entre fotografía material y fotografía formal lo que marca es el período histórico que delimita la propia existencia de la fotografía formal como tal, que alcanza desde la invención de Daguerre, hasta la aparición del ordenador y de los programas de tratamiento de imágenes, y posteriormente, la fotografía digital. Las imágenes anteriores, si hacemos caso a lo que decía el pintor David Hockney, son ellas ya, en gran medida, fotografías materiales, mientras que las imágenes digitales es prácticamente imposible que se conserven como fotografías formales. Esta distinción es absolutamente esencial, como puede observarse en cualquier proceso legal, y en múltiples situaciones en donde la fotografía es apelada como fuente de verdad y objetividad.

Recordemos el escándalo que hace poco tiempo se suscitó a raíz del montaje fotográfico de la Familia Real con motivo de la Navidad, en donde aparecían los nietos recortados de distintas fotos y colocados allí. Ciertamente, en

\footnotetext{
${ }^{8}$ Véase Wikipedia, "Fotografías acusadas de trucaje", donde aparecen muchos ejemplos diversos.
} 
muchos casos, como este, no tiene ninguna importancia, salvo para quienes estén tomándose en serio la institución monárquica (lo que, en nuestro caso, no es discutible, ya que somos una Monarquía parlamentaria, de manera que efectuar una manipulación de ese tipo, con las connotaciones de falsedad formal que ello supone, resulta ciertamente embarazoso, y requeriría explicaciones).

En la fotografía que le dio el premio Pulitzer a Kevin Carter en 1994, la disposición de los elementos de la imagen: la niña moribunda y el buitre, no puede darse mediante una manipulación. Lo que le otorga el carácter de fotografía excepcional es el hecho de que es una fotografía formal. Tal resultó ser su elocuencia, que atormentó a su autor conduciéndole al suicidio. La posibilidad no remota de que las tecnologías informáticas de tratamiento de imágenes no dejen rastro de las posibles manipulaciones sobre las imágenes, dejando sólo a la buena voluntad del autor la confianza en la formalidad de la imagen hace que en la era digital tengamos que decirle adiós a la fotografía formal.

\section{Fotografía formal y fotografía verdadera}

En todo caso, esta distinción no tiene una estricta connotación moral, porque no se trata de que la fotografía formal sea la buena fotografía, y la material, mala. Por ejemplo, puede darse el caso de que una fotografía formal de uso científico sea manipulada con fines divulgativos, o didácticos, etcétera. Pero, obviamente, sí tendrá que ver con la cuestión de la verdad y la falsedad. Al menos, la concepción formal de la fotografía permitirá distinguir dentro del género de las imágenes fijas hechas por los hombres desde tiempos inmemoriales, la especie de aquellas que son realizadas por máquinas fotográficas, mediante un proceso químico o digital de "revelado", y cuyo resultado, la composición de formas resultantes, no son manipuladas directamente por el ejecutor, que ya no es un pintor, artista o artesano, sino un fotógrafo.

Con ello, se advierte que la fotografía comparte con la televisión formal, tal como la define Gustavo Bueno, la característica que satisface también el requisito de la interesección de la línea estructural y de la línea de contenido en la fotografía formal, esto es, la clarividencia. Porque también la fotografía nos pone ante acontecimientos y situaciones que trascienden nuestra capacidad de percepción, y en virtud de esta capacidad de clarividencia, la fotografía estaría en el camino de conformación de la televisión misma: "la novedad específica de la televisión, en cuanto instrumento representativo, pide ser insertada en la serie de otras neogénesis específicas que desempeñan, respecto de la televisión, el papel de un género generador. Porque estas especies de instituciones o de instrumentos representacionales, que flanquean a la neogénesis televisiva, no constituyen un mero cortejo de acompañamiento externo. Se trata de especies que han ido surgiendo "apoyándose" las unas en las otras. Pongamos por caso: la especie de las representaciones teatrales, la 
especie de las representaciones por espejos, por pinturas, y más tarde la cámara oscura, el telescopio, la fotografía, la cinematografía o la radio." ${ }^{9}$

En todo caso, no parece que una fotografía por ser formal sea necesariamente verdadera, en cuanto a lo que el espectador ve en ella. Al margen de las cuestiones de la manipulación, una fotografía formal puede ofrecer una información falsa debido a la intención determinada por el autor de la fotografía. $Y$ nos parece que en el caso de que la fotografía siga siendo formal, su verdad sólo podrá ser reivindicada por otras fotografías dadas desde otros encuadres, y en otros momentos de la misma escena, que confirmen lo que la foto original pone de manifiesto. No hay otro modo de determinar la verdad de una fotografía formal, si no es mediante la composición de otras fotografías sobre la misma escena, o en el caso de fotografías formales científicas, la repetición de la fotografía con los mismos resultados.

En efecto, podemos recordar el caso de la fotografía Miliciano abatido en Cerro Muriano (1936) de Robert Capa, en el que este extraordinario fotógrafo fue acusado de haberla preparado. La acusación resultó desmentida precisamente por la serie de fotografías tomadas antes y después de la fotografía seleccionada, que mostraban el acontecimiento bélico con toda claridad ${ }^{10}$. Por contraposición, podemos recordar el caso de la fotografía de Javier Bauluz, Pareja en la playa con cadáver, o Inmigrante muerto en la playa de Zahara de los Atunes (2000). En efecto, esta fotografía, aun siendo formal, es desmentida, porque las fotos tomadas desde otros encuadres ponen de manifiesto que la pareja no está indiferente ante el cadáver, puesto que está la Guardia Civil, etc. Esta parece ser la razón por la que Arcadi Espada denuncia que no se trata de una fotografía verdadera, aunque sí pueda ser una verdadera fotografía (formal). En este caso, lo que queda en entredicho es la confianza en el fotógrafo, aunque su intención reivindicativa pueda ser legítima. Una fotografía formal de este tipo tendrá sentido como ocurrencia del autor, y su resultado estaría en la línea de las extraordinarias formas conseguidas en las fotografías de Joan Colom en el barrio del Raval de Barcelona en 1960. El hecho de que una foto sea formal es, sin embargo, esencial para poder hablar de una foto

\footnotetext{
${ }^{9}$ Gustavo Bueno, Op. cit.,; pág. 189.

${ }^{10}$ A partir del año 2007 crece la duda razonable sobre la posibilidad de que la fotografía del miliciano resulte ser una fotografía preparada. En efecto, desde el documental La sombra del iceberg, de Hugo Doménech y Raul Riebenbauer, de 2007, y los posteriores estudios de Ernest Alós, parecen indicar que se trataría de una fotografía formal, una verdadera fotografía falsa. Posteriormente, el libro de José Manuel Susperregui, Las sombras de la fotografía, Universidad del País Vasco 2009, han dejado más claro que el acontecimiento al menos no ocurrió en Cerro Murriano sino cerca de la localidad de Espejo, aunque caben algunas dudas aun acerca de si la fotografía realmente presenta un acontecimiento verídico o un montaje. Los argumentos esgrimidos apuntan a los parámetros racionales propios para discriminar una verdadera fotografía, esto es, la búsqueda de otros puntos de vista, que pueden dar luz sobre el acontecimiento, y el estudio de la posible manipulación, así como la serie fotográfica correspondiente. No habría propiamente manipulación del cliché, pero sí una información falsa del lugar y del acontecimiento narrado. En todo caso, fueron precisamente las 40 fotografías conservadas realizadas en la misma jornada por Capa y Gerda Taro, publicadas por primera vez en 2007 por el ICP de Nueva York, las que han permitido arrojar más luz sobre el asunto. Por ello, retiramos estas afirmaciones hechas en un momento en que estas nuevas aportaciones no se conocían.
} 
verdadera, y ello es lo que da garantía a su uso en un proceso judicial, por ejemplo.

Pero la fotografía material, no por ser falsa fotografía es necesariamente fotografía falsa. Hay fotografías manipuladas que no son falsas, mientras que otras fotografías materiales si lo son de hecho. En los ejemplos que antes hemos comentado, una fotografía como la de Chaldej a pesar de ser una fotografía material si es que es cierto que se borró el reloj de pulsera y se puso un poco de humo en el horizonte, no dejará por ello de ser verdadera, porque lo que enuncia la fotografía como tal no podría falsearlo ninguna otra fotografía hecha en el momento. Ni en la denotación de la fotografía, ni en la connotación, se alcanza una transformación del contenido de la imagen. Una fotografía como la de Franco con Hitler en Hendaya, en la que se retocó la mano de Franco para que no diera la impresión connotativa de un gesto afeminado, no desmiente la verdad de esa fotografía, y por ello, aun siendo material, sigue siendo verdadera. Un caso de fotografía material falsa claramente lo representa la fotografía de Lenin en el mitin ante el Bolshoi, en Moscú, porque lo retocado sería desmentido por otras fotografías, así como por la original.

\section{La fotografía: de lo bello a lo siniestro}

Aristóteles advertía en la Poética que la imitación trae consigo un goce: "Prueba de ello es lo que ocurre en la realidad: cosas que vemos con desagrado en el original nos causan placer cuando las contemplamos en imágenes lo más fieles posible, como ocurre, por ejemplo, con la representación de los animales más repugnantes o con animales muertos" (IV). Este extrañamiento que produce la imagen con relación al original representado es la condición esencial para hablar de belleza y aun de arte, según la Crítica del juicio de Kant: "El arte bello muestra precisamente su excelencia en que describe como bellas cosas que en la naturaleza serían feas o desagradables. Las furias, las enfermedades, devastaciones de la guerra, etc., pueden ser descritas como males muy bellamente, y hasta representarlas en cuadros". Ya se sabe que para Kant lo único que está fuera de esta posibilidad estética es "lo que despierta asco". Pero, en fin, lo que nos interesa resaltar aquí es que esa sombra de lo siniestro que se cuela tras la representación artística, la pone de manifiesto el acontecimiento tecnológico de la fotografía. El asco no sería más que "una de las especies de lo siniestro". Si nos atenemos a la definición de lo siniestro que propone Trías, cuando establece su hipótesis: "lo siniestro constituye condición y límite de lo bello" ${ }^{11}$, habría que decir que precisamente la emergencia de la fotografía formal, frente a la recreación tradicional de las imágenes, tal como apunta Hockney, constituyó, por su clarividencia, la irrupción de lo siniestro y el abandono del criterio de belleza como imitación hasta entonces invocado. Por cierto que los grabados de Goya estarían anticipando ya este tipo de representación siniestra, contradiciendo la tesis de Kant, porque en ellos la belleza queda subordinada a la verdad terrible que queda reflejada también en formato

\footnotetext{
${ }^{11}$ Eugenio Trías, Lo bello y lo siniestro, Ariel, Barcelona 1988; pág. 17
} 
bicolor. Evidentemente, las planchas a partir de las cuales se reproducen los grabados son una prefiguración efectiva de los negativos fotográficos.

Por primera vez, la representación fotográfica consigue superar esa frontera que desde Aristóteles hasta Kant se había establecido entre la cosa y su representación, que propiciaba que de algo siniestro pudiera darse una imitación bella. La fotografía, por su clarividencia, rompe el extrañamiento y hace desaparecer el llamado "efecto estético". Aunque pueda recuperarse, la clarividencia de la fotografía formal no se mantiene en el terreno de la belleza, sino en el de la verdad. Por esa razón, la fotografía alcanza, según todos los intérpretes, el mayor grado de formalidad en el llamado fotoperiodismo, y particularmente en el fotoperiodismo de guerra. Trías señala que la irrupción de lo siniestro se produce con el romanticismo, pero no toma en consideración el papel de la irrupción histórica de la fotografía como acontecimiento tecnológico y ontológico en el siglo XIX, como punto de ruptura y de crisis de esa concepción de la belleza tradicionalmente ligada a la recreación mimética de lo representado.

"En general, sugiere Freud, se da lo siniestro cuando lo fantástico (fantaseado, deseado por el sujeto, pero de forma oculta, velada y autocensurada) se produce en lo real; o cuando lo real asume enteramente el carácter de lo fantástico", dice Trías. "Se da la sensación de lo siniestro cuando algo sentido y presentido, temido y secretamente deseado por el sujeto, se hace, de forma súbita, realidad". Lo siniestro "es la verificación de una fantasía formulada como deseo, si bien temida"12. Pues bien, en gran medida, eso es lo que hace la fotografía: ponernos ante acontecimientos, verificar como reales, situaciones imaginables, temibles, inconcebibles, tal vez en otros lugares, o en otros momentos. Esto es lo que hace la fotografía formal, levantar acta de lo que ocurre. Quitémosle la carga de responsabilidad y culpabilidad a nuestras propias fantasías y contemplemos la fotografía como la primera técnica de clarividencia que nos pone ante lo ocurrido de manera descarnada y verdadera.

\section{Fotografía formal manipulada verdadera}

Pero no siempre una fotografía formal con manipulación es necesariamente una fotografía falsa. Es el caso de las fotografías científicas, o de las fotografías de diagnóstico, hechas con diversas técnicas. En ellas, siempre hay un aprovechamiento de las posibilidades tecnológicas de los aparatos fotográficos más desarrollados, pero sus resultados no son falsos, por más que el científico de turno busque el enfoque preciso y la perspectiva adecuada, el resultado de estos enfoques no pretende falsear, sino confirmar o descubrir. Este mismo carácter formal de la fotografía es el que ha ayudado en el desarrollo de la ciencia de maneras diversas. Pongamos una cámara convenientemente preparada tomando una fotografía del cielo con el obturador abierto durante varias horas. El resultado podrá ser la representación del movimiento rotatorio de la tierra en el círculo trazado por la estela de luz de las estrellas. Pensemos en el descubrimiento de los rayos $X$, 0 en el

\footnotetext{
${ }^{12}$ Eugenio Trías, Op. cit., pág. 35
} 
descubrimiento de la estructura de la doble hélice, donde una fotografía abrió el camino para la determinación de la forma helicoidal. "Hugh [Huxley, responsable de la llave del laboratorio Cavendish donde se había construido un poderoso supertubo rotatorio de rayos $X$ anódicos] no estaba en el laboratorio cuando, a última hora de una noche de junio, volví para apagar el tubo de rayos $X$ y revelar la fotografía de una nueva muestra de VMT. Tenía una inclinación de 25 grados, de forma que, con suerte, quizá podría encontrar los reflejos helicoidales. En cuanto coloqué el negativo, aún húmedo, sobre el papel luminoso, supe que lo habíamos logrado. Las señales que revelaban una hélice eran inconfundibles." 13 En todo caso, fueron las fotos de Rosalind Franklin las que verdaderamente ayudaron al descubrimiento.

Hay otro asunto que me interesa destacar en cuanto a la vinculación de la historia de la fotografía con la historia de la ciencia, relativo a la distinción entre fotografía material y formal. Nos referimos a la historia de la microscopía, porque en ella se desarrolla una técnica de elaboración de preparados sobre cristal, una especie de diapositivas, que son resultado de pequeñas muestras extraídas de los tejidos estudiados. Esas muestras "cortan" la realidad física y temporalmente también (de la misma manera que la fotografía formal), y fijan el objeto de estudio para su descripción posterior. Son técnicas que se remontan ya hasta Robert Hooke, en el siglo XVII. Sus manipulaciones en absoluto modifican las formas estudiadas, sino que consiguen más bien resaltarlas y contrastarlas mediante distintas técnicas fijando las muestras para su posterior descripción y estudio. Con ellos incluso se secuencian procesos celulares fijados en distintas muestras, etc. A finales del diecinueve Retzius describió muchos tejidos animales con una precisión extraordinaria. Ramón y Cajal diseñó métodos de tinción que sentaron las bases de la anatomía microscópica, y dejó grandes cantidades de muestras, cortes, o "películas". El desarrollo de la microscopía electrónica y las nuevas técnicas de microtomía han permitido a los científicos estudios cada vez más precisos de entidades físicas casi inconcebibles. Ya en 1943, K. Michel realizó, por ejemplo, la primera película sobre la división de las células con ayuda de un microscopio de contraste de fase, etc. En este sentido, cabría decir que la historia de la fotografía formal se extiende hasta los inicios de la elaboración de preparados para la observación del microscopio, porque en ellos se fijan formas, aunque, ciertamente mediante un procedimiento no "fotónico".

Por otra parte, el uso de las placas fotográficas ha sido esencial para todo el desarrollo de la física durante el siglo XX, tanto como objeto de reflexión, por ejemplo, para observar la naturaleza probabilística, la confirmación del comportamiento mecánico-cuántico de la luz en el proceso de conformación de la imagen en la emulsión de plata, pero también en las investigaciones para el desarrollo de dispositivos de observación tales como el microscopio electrónico, que permiten establecer una distribución de campos eléctricos y magnéticos que actúan sobre los electrones de forma análoga a como lo hacen las lentes de cristal sobre la luz. El fundamento de estos dispositivos es el mismo en virtud del cual se han llegado a construir los grandes aceleradores de partículas que han permitido ampliar el conocimiento y la perplejidad sobre la

\footnotetext{
${ }^{13}$ James D. Watson, La doble hélice, Alianza, Madrid 2000; capítulo 18.
} 
materia, y aunque no dan como resultado imágenes interpretables, sí se utiliza la llamada cámara de niebla para detectar lo que están buscando. Los espectroscopios ya concebidos por Kirchhoff sufrieron un importantísimo desarrollo con el descubrimiento de la fotografía que permitió la creación de aparatos más precisos y la fijación de los resultados. También los espectrógrafos fueron concebidos a partir de la existencia del papel fotográfico. La ley de Hubble, por ejemplo, fue establecida gracias al uso de espectrógrafos que utilizaban papel fotográfico. El efecto Doppler también ha podido ser estudiado mediante el espectrógrafo.

\section{La fotografía en los tres géneros de materialidad}

La fotografía como acontecimiento tecnológico supone una transformación de nuestra visión del mundo, y del propio mundo. En este sentido, sería necesario hablar de diversos tipos de fotografías formales verdaderas, puesto que estas fotografías científicas nos ponen ante acontecimientos gnoseológicos nuevos y extraordinarios, a veces increíbles, como las fotografías con microscopio electrónico de la cabeza de un alfiler, o de un grupo de ácaros del polvo con apariencia de estar pastando en el campo. Todas ellas nos ponen en imagen realidades invisibles para el ojo humano. Por no hablar de fotografías como las de átomos individuales de torio depositados en una película de carbón, que por sus características especiales pueden ser visualizados en una placa fotográfica. A este tipo de imágenes cabría catalogarlas en el ámbito ontológico terciogenérico, en el sentido de los tres géneros de materialidad que propone Gustavo Bueno en sus Ensayos materialistas, entre otras cosas porque se trata de imágenes buscadas mediante la mejora de los procesos técnicos, y previstas por la investigación científica, invisibles para el ojo, etc.

Habrá también imágenes fotográficas segundogenéricas, tales como las que Auggie captaba con su cámara todas las mañanas, durante catorce años, a la puerta de su estanco, en la película Smoke (USA, 1994), de Wayne Wang. Este tipo de fotografías son las que más éxito han tenido, y normalmente es en ellas en las que se piensa cuando se habla de fotografía. Se dice que la fotografía contribuye a configurar nuestra memoria vital. Antonio Muñoz Molina recuerda que Baudelaire, al parecer, acusaba a la fotografía de invadir y corromper la memoria, igual que Sócrates en el Fedro denuncia que la escritura desvanece la memoria requerida por el lenguaje oral. La fotografía está asociada a la conservación de los recuerdos, eso es obvio. En la película Blade Runner (USA, 1987), de Ridkey Scot, se insiste en la idea de que los replicantes buscan en las fotografías la prueba de su humanidad, y con ellas se les "refuerzan" los "implantes" de recuerdos para que no sepan que son verdaderamente replicantes. Enrique Moradiellos, por ejemplo, en su libro sobre la vida de Juan Negrín ${ }^{14}$, recuerda que este insigne científico y excepcional político español llevó toda su vida consigo una fotografía en la que aparece él con una de sus hijas muerta. Ciertamente, cundió durante un tiempo la costumbre de fotografiar cadáveres, y particularmente niños, como recuerdo,

\footnotetext{
${ }^{14}$ Enrique Moradiellos, Negrín. Una biografía de la figura más difamada de la España del siglo $X X$, ed. Península, Barcelona 2006. Un libro extraordinario en todos los sentidos.
} 
lo que por otra parte no resulta nada extraño. También en los cementerios muchas lápidas vienen acompañadas de una fotografía de tipo carné en la que se recuerda al finado vivo, y cualquiera que pasee por el cementerio agradece ese detalle informativo.

Siguiendo con esta clasificación ontológica, nos parece que seguramente el ámbito primogenérico estaría dado por el mismo artefacto de la fotografía hecha imagen en papel. La razón de clasificar las fotografías verdaderas en sentido formal según esta división podría radicar, suponemos, en el tipo de relaciones que se establecen entre los elementos que aparecen representados en las fotografías. Pero esto es algo que sólo podemos dejar apuntado.

\section{Fotografía y realidad}

La fotografía supone, se dice, la congelación del instante, eternizar un momento. Evidentemente, más que eternizar, lo que hace la fotografía, en términos aristotélicos, es transformar un tipo de movimiento, por ejemplo, de traslación, en otro tipo de movimiento, el de generación y corrupción. La fotografía capta un instante de una situación originalmente en movimiento, y produce una fotografía en papel cuya existencia va a estar mediada entre otras cosas, por el cuidado con el que se ha limpiado de líquidos el papel fotográfico, su calidad, su fijación, etc.:

"Algún día se pondrá el tiempo amarillo sobre mi fotografía" dice un verso de Miguel Hernández.

Pero lo interesante de la fotografía, en este sentido, no viene tanto del hecho de "congelar" el instante, sino de hacerlo a escala no metafísica (un instante especulado como el cero del tiempo, etc.), sino operatoria. Porque una serie de fotografías tomadas convenientemente según el tiempo, y dispuestas en una secuencia temporal adecuada, gracias a la llamada "persistencia retiniana", reconstruye el movimiento tal y como éste se generó. Sobre este fundamento se construye la técnica cinematográfica y la técnica televisiva, puesto que también la televisión trabaja con imágenes fijas representadas por el haz de electrones sobre la pantalla, con una frecuencia de unas 26 imágenes por segundo.

En todo caso, las imágenes fotográficas no reconstruyen "la realidad" tal y como esta es, como ocurría en la novela extraordinaria de Bioy Casares, La invención de Morel. En ella se narra el extraño caso de un náufrago que arriba a una isla habitada y deshabitada periódicamente por personajes que repiten exactamente todas sus acciones. En efecto, como se sabe, una máquina, la invención de Morel, tenía capacidad de grabar y reproducir, aprovechando el flujo de las mareas, la realidad de la isla, de tal manera que la imagen resultante es tridimensional, un bulto. Obviamente el náufrago se enamora de una mujer "grabada", Faustine, cuya imagen difiere de la realidad solamente por la rigidez que produce todo su cuerpo al tocarla, puesto que está, por así decir, en otra dimensión (de la misma manera que quien besa la imagen de la novia en la fotografía, realmente está besando el soporte en papel de esa 
imagen, y a lo sumo recibirá los efluvios de los químicos utilizados en el revelado).

En esta novela la fuerza de las imágenes es tal que el náufrago no puede sobreponerse a ellas, a Faustine. No hay esclavos liberados como en el Mito de la caverna, y el único esclavo pide ser esclavizado sin retorno, pone en marcha la invención y se graba a sí mismo al lado de Faustine, después de haber estudiado todos sus movimientos y haber ensayado los suyos propios. Nunca estará con Faustine, pero al menos lo "parecerá" para quien vea esas imágenes después. Por eso pedirá al final a quien leyere ese informe: "hágame entrar en el cielo de la conciencia de Faustine. Será un acto piadoso". Por lo demás, se trataría simplemente de un caso de fotografía material manipulada.

\section{Fotografía e imagen}

Tal vez, el auge de la fotografía suponga la muerte de las imágenes, según la tesis de Fritz Saxl, en La vida de las imágenes ${ }^{15}$. La tesis de Saxl es extraordinariamente interesante, y pone de manifiesto que determinados patrones y formas nacidas en un momento histórico concreto tienen una vida y un significado cultural y antropológico preciso durante un tiempo, pueden renacer y reformarse de nuevo, aunque finalmente la vida huye de ellas y se convierten, o bien en objetos decorativos, o de estudio arqueológico, con el propio declive del contexto cultural e ideológico en el que nacieron. ¿Es posible que Saxl no haya visto en El Guernica, que analiza en el último capítulo de su libro, la recreación de la imagen del Belén con sus pastorcillos, sus animales (la mula y el buey convertidos en caballo y toro), sus angelitos, la virgen y el niño y San José armado, reventados por las bombas que se cuelan como la estrella de Belén -que nos perdonen los críticos de arte?

La irrupción de la tecnología digital ha abierto nuevos horizontes para la investigación científica basada en la observación y elaboración de imágenes, la astronomía, la investigación biológica, la medicina, etc., y ha generado la multiplicación del mundo de las imágenes. Iconosfera llama a nuestro mundo Román Gubern ${ }^{16}$. Estamos plagados de imágenes que se suceden en el espacio y en el tiempo, con cada una de las nuevas perspectivas abiertas a cada uno de nosotros cuando tenemos a mano un dispositivo fotográfico, un teléfono móvil, una cámara digital de vídeo o de fotografía. Pero la digitalización permite también la manipulación infinita de la imagen. La muerte de las imágenes (de la fotografía en sentido formal) por multiplicación, tiene un verdugo implacable, el botoncito "print screen" de nuestros teclados, que convierte todo lo que se nos presenta en la pantalla en una nueva imagen manipulable, retocable y montable, una y otra vez, y hasta el infinito.

\footnotetext{
${ }^{15}$ Fritz Saxl, La vida de las imágenes, Alianza, Madrid 1989.

${ }^{16}$ Véase, entre otros extraordinarios trabajos de Román Gubern, Del bisonte a la realidad virtual. La escena y el laberinto, Anagrama, Barcelona 1996.
} 


\section{Segunda parte: Algunas consideraciones metodológicas}

\section{Sobre la formalidad de la fotografía}

"No se trata, por tanto, de poner en cuestión la realidad de la confluencia efectiva de todos esos cursos o corrientes en la televisión "efectivamente existente", una realidad a la que podemos designar, desde luego, como televisión material. De lo que se trata es de determinar si cabe asignar alguna diferencia o conjunto de diferencias al ente televisivo, tales que permitan hablar, en el conjunto de los medios de comunicación, mutuamente intersectados, de una estructura o forma diferencial significativa de la televisión. La cuestión, por tanto, es la de si existe o no existe una televisión formal que mantenga su estructura y sus funciones sin dejar por ello de formar parte, en cuanto televisión material, de ese magma o masa mediática constituida por todos los medios de comunicación en incesante intersección e influencia recíproca."17

Cuando hablamos en nuestro ensayo de "fotografía formal" siguiendo la nomenclatura usada por Gustavo Bueno en su extraordinario libro, no lo hacemos, obviamente, suponiendo que la fotografía es televisión formal, o que la fotografía es formal porque es clarividente en el presente escénico, como lo es la televisión formal. La clarividencia "en directo", del presente escénico no era posible en fotografía "analógica", salvo en el caso de las famosas Polaroid (con un "falso directo"), y en el caso actual de las cámaras fotográficas digitales (aunque el asunto de los medios digitales debe tratarse aparte porque, como tal, en el mundo de la tecnología digital hablar de cámara fotográfica, cámara de vídeo, teléfono, etc., es demasiado comprometido; estos medios digitales lo han revolucionado todo, pero vamos a ceñirnos al ámbito analógico, por así decir, para dejar claro por qué hablamos de fotografía formal). Al contrario, la fotografía es formal cuando es el fruto genuino del medio que la constituye, la cámara fotográfica y el laboratorio de revelado. Al igual que la televisión es formal cuando es el fruto genuino del medio que la constituye: la cámara de televisión y el proceso de emisión y recepción tecnológica que permite ver la imagen en "directo".

De la misma manera que el directo es el fruto genuino de la televisión formal, la fotografía no manipulada es el fruto genuino de la fotografía formal, de la llamada "verdadera fotografía". Y, así como la televisión material es un sucedáneo del medio televisivo, la fotografía material es un sucedáneo del medio fotográfico. $Y$ así como una emisión en directo puede ser un engaño (una "apariencia falaz"), también una verdadera fotografía puede no ser verdadera (renunciamos en todo caso a multiplicar los términos llamando "apariencias" (veraces o falaces) a las fotografías, porque evidentemente no toda apariencia es fotográfica, también la imagen televisiva es una apariencia, aunque sea en directo).

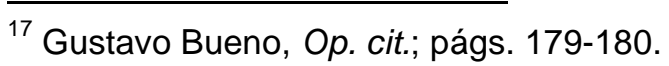


Gustavo Bueno ha dicho, en efecto, que

"lo que caracteriza a la televisión formal, y aun a la televisión frente a cualquier otra forma de visión (...) es su clarividencia, es decir, su capacidad para permitirnos ver, no ya "a lo lejos" (porque entonces, toda visión, y en particular la visión telescópica, sería televisión), sino remontando los obstáculos de los cuerpos ópticamente opacos que se interponen entre mis ojos y las realidades televisadas"18.

Es ahí donde, siguiendo la pauta mcluhiana según la cual "el medio es el mensaje", sitúa Bueno la televisión formal, porque esa característica es la que distingue formalmente al medio televisivo de cualquier otro:

"La cuestión fundamental reside, en todo caso, en la determinación de la especificidad de la estructura mediática de la televisión. Y ocurre que los análisis que suelen ser ofrecidos sobre el particular dejan fuera de su cuadro lo que en este Ensayo venimos considerando como la característica específica esencial del medio, a saber, su clarividencia; una característica que es indisociable de su misma novedad tecnológica." ${ }^{19}$

Sin embargo, reconoce también, y esto es fundamental, que

"la clarividencia, que es una característica necesaria y suficiente para definir la televisión formal, no es suficiente para distinguir la televisión formal de la televisión material. Porque [NB] la clarividencia alude, inicialmente, a la visión a distancia de contenidos apotéticos que no sólo están dados en el espacio a distancia, tras cuerpos opacos, sino que han de estar dados en el espacio tiempo, en presencia causal real del televidente."20

De donde resulta la distinción entre televisión formal y material. La televisión formal se corresponderá con la televisión en directo o en tiempo real -algo por lo demás, admitido en los más básicos manuales sobre el medio televisivo. Dice por ejemplo Domènec Font en El poder de la imagen:

"La característica más elemental del medio televisivo y lo que configura su lenguaje específico es el directo. El modelo televisivo está, en principio, anclado en el desarrollo vivo y dinámico de los acontecimientos, en cuya evolución el telespectador cree ser partícipe por el mero hecho de situarse frente a las imágenes. Grandes acontecimientos políticos y deportivos proyectados múltiple y simultáneamente a través de los satélites, entrevistas callejeras y objetivos indiscretos dan una sensación de presencia activa. Esta inmediatez del sonido y la imagen, definen la propia estructuración de los mensajes y adecuan las reacciones del espectador. Texto y contexto parecen coincidir y llegar al receptor sin intermediarios ni manipulaciones. Es más, parece que no interviene ni el propio aparato que refleja el directo como ese

\footnotetext{
${ }^{18}$ Bueno, Op. cit., págs. 217-218.

${ }^{19}$ Bueno, Op. cit., pág. 325.

${ }^{20}$ Bueno, Op. cit., pág. 218.
} 
hombre-ojo convertido en invisible cámara tomavistas para recoger in situ la agonía de una mujer, por encargo de la NBC americana en la película de Bertrand Tavernier, La muerte en directo." 21

La televisión material incluirá la clarividencia, atención, pero no el directo:

"Otra cosa es la posibilidad -dice Bueno- de una desconexión entre el tiempo en el que se han dado determinados contenidos y el momento de su transmisión televisada; desconexión que tiene lugar siempre que esos contenidos hayan sido "grabados", en película o vídeo. Una tal desconexión instaura ese tipo de televisión que venimos llamando televisión material; porque en ella, la "presencia clarividente" sólo puede ir referida al acto mismo de la transmisión técnica, pero no a los contenidos transmitidos." 22

Ahora bien, si la clarividencia se predica no ya de la transmisión en directo, sino de la transmisión técnica, de la difusión de una imagen previamente grabada, ¿consiste acaso sólo en el hecho mismo de que entre la fuente emisora de la señal y la televisión receptora sigue estableciéndose un vaciado de cuerpos opacos interpuestos? Si ello fuera así, entonces la clarividencia no es la única característica de la televisión formal, sino precisamente el directo entendido como "dramatismo clarividente":

"el "dramatismo" que atribuimos a la televisión formal tiene que ver, por tanto, con el hecho, algunas veces muy relevante desde el punto de vista técnico, de que los sucesos escénicos televisados estén produciéndose en el momento mismo de la transmisión, es decir, estén causando, en un proceso continuo, efectos suyos, las imágenes percibidas por el sujeto receptor. Se trata de una situación en la que la secuencia de los sucesos percibidos podría interrumpirse o tomar un rumbo diferente al previsto (...) Esto no puede ocurrir con la mera televisión material, cuyos contenidos se supone que están ya dados, y aun de modo irrevocable."23

La única improvisación que cabe en la televisión material es, por ejemplo, que se estropee la fuente emisora, o el mismo receptor, o el mismo documento videográfico grabado.

Por ello, para nosotros, la clarividencia es genérica a muchos medios, también a la fotografía, al vídeo y a la radio (aquí habría que hablar de una especie de "clariaudiencia"); porque todos ellos pueden dar lugar a un mensaje clarividente en el tiempo y en el espacio. La clarividencia hay que componerla con la instantaneidad, con el presente escénico, para encontrar la especificidad de la televisión formal. Nosotros hemos encontrado también la característica específica y diferencial de la fotografía formal en la imagen producida por la cámara sin manipulaciones, y la llamamos formal precisamente en virtud de su carácter diferencial. Al igual que la televisión formal tiene como característica la

\footnotetext{
${ }^{21}$ Domènec Font, El poder de la imagen, Salvat, Barcelona 1985; pág. 52

${ }^{22}$ Bueno, Op. cit., pág. 218.

${ }^{23}$ Bueno, Op. cit., pag. 219.
} 
clarividencia en directo, instantánea, sólo espacial, la fotografía formal sería clarividente en el espacio y en el tiempo, precisamente por su carencia de instantaneidad. En efecto, una fotografía no manipulada, formal, establece un tipo de clarividencia porque nos permite ver "a través del tiempo" interpuesto entre el momento en el que se toma la fotografía y en los tiempos diferentes en los que es vista. ¿Acaso no es este un caso magnífico de clarividencia, la clarividencia temporal? La radio formal, por ejemplo, es clariaudiente en el espacio pero no en el tiempo; lo será la radio que podríamos llamar material (previamente grabada).

Decimos que vemos el pasado en esas apariencias fotográficas veraces en el sentido que el propio Bueno ofrece en el libro que estamos considerando, en relación con la televisión formal:

"El pretérito será el lugar en el que situamos aquellas escenas que pueden seguir influyendo sobre los sujetos operatorios actuales, sin que nosotros podamos ya influir sobre ellas; y el futuro será el lugar de los sujetos sobre los cuales nosotros podemos influir sin que ellos puedan, ni directa ni indirectamente, influir sobre nosotros"24.

Evidentemente, por tanto, la clarividencia temporal no puede permitir en absoluto la modificación de los acontecimientos, que deben mostrarse, precisamente por darse en el pasado, de manera absolutamente irrevocable.

El presente televisivo será aquel en el que "los sujetos operatorios pueden influirse, a través de la televisión, mutuamente" (incluye Bueno aquí el falso directo -pág. 222). La televisión material, en todo caso, nos pondría en presencia actual del pretérito; al igual que haría la fotografía formal, pues es precisamente ésa la especificidad del medio fotográfico; también videográfico, y cinematográfico. No obstante, la clarividencia y la clariaudiencia, así como la televisión formal (clarividencia espacial) han quedado subsumidas en el mundo de los media digitales; las webcams por ejemplo, dan ciento y raya a la televisión formal, siempre sometible a múltiples manipulaciones. Es importante señalar, en todo caso, que la clarividencia temporal de la fotografía define una verdadera fotografía, pero no necesariamente una fotografía verdadera, al igual que la clarividencia en el presente escénico del mensaje televisivo define un verdadero mensaje televisivo, pero no necesariamente un mensaje televisivo verdadero, porque en el proceso de emisión la realización puede hacer una composición que produzca una apariencia falaz, como reconoce Bueno en muchos pasajes de su libro.

\section{Fotografía y clarividencia}

No hay televisión sin fotografía. El fundamento de la televisión clarividente es la fotografía formal verdadera, y su fuerza de convicción depende del hecho de que la sucesión de imágenes fijas, 26 por segundo, confirma cada una de las fotografías que componen la sucesión, al menos en cuanto son percibidas por

${ }^{24}$ Bueno, Op. cit., pág. 222. 
el ojo humano, y salvo análisis por descomposición de cada una de las imágenes fijas en la medida en que pueda dar lugar a descubrimientos de imágenes subliminales, por ejemplo. En todo caso, la verdad del mensaje televisivo no depende del hecho de que se vea en el instante en que se emite, sino en que lo que se vea, independientemente de que corresponda al mismo momento en que se está produciendo el hecho, no haya sido manipulado, sino grabado directamente sin mediación. Una grabación por parte de una cámara de vídeo de un banco, de cómo tres etarras preparan un crimen, no es verdadera porque sea vista en tiempo real, sino porque se sabe que no ha sido manipulada, que su proceso de grabación es automático, incluso cuando, como ocurre en este caso, se hace conforme a una serie de imágenes fijas más baja que la necesaria para una visión continua (para una apariencia de continuidad).

La verdad televisiva está no en el hecho de que la emisión sea instantánea, sino continua, no en que se vea cuando se emite, sino en que lo que emite sea automático, no manipulado, esclavo del mecanismo que lo recoge. O acaso se piensa que una emisión instantánea de los Juegos Olímpicos de Pekín es más verdadera por el hecho de que se vea al instante, aunque se utilice en el montaje, por ejemplo, la composición de cientos de cámaras dispuestas en distintos lugares grabando a la vez. Y lo mismo cabe decir de programas concebidos para el "directo" como El gran hermano, donde el proceso de realización por montaje sigue, y ha seguido siempre, los parámetros de cualquier vulgar telenovela. El operario decide constantemente cambiar de plano, introducir un ambiente musical, etc. El espectador ve al instante el montaje, pero no por eso deja de ser un montaje, y en cuanto tal, aunque sea instantáneo, es manipulado -recordemos, por ejemplo, el llamado "efecto Kulechov", fundamento del cine soviético y del montaje videográfico en general, que estudia las asociaciones interpretativas que establece el sujeto receptor en función de la composición de planos. Si a eso añadimos el texto y la voz, la imagen televisiva instantáneamente emitida por diversas cámaras y vista no tiene por qué dejar de ser imagen manipulada.

El caso límite de la televisión no manipulada no está en la visión instantánea, sino en la grabación continua sin cortes ni manipulaciones, automática: una cámara emitiendo todo el día y a todas horas desde el muro de Gijón a la gente que pasa, que puede ser vista por un internauta en el instante (retardado por la velocidad de conexión, por ejemplo), o bien por un policía que revisa los archivos grabados por esa cámara buscando a un etarra que posteriormente explosionó un coche en las inmediaciones de la zona. No es el hecho de que se emita y se vea instantáneamente lo que garantiza la verdad de lo visto, sino cómo se recoge la información. Y la forma de recoger la información es mediante la composición de fotografías formales a razón de 26 fotografías por segundo, en la televisión, 24 en el cine, y en general, en cualquier dispositivo digital, en el que el fundamento sigue siendo la sucesión de imágenes fijas. Tan verdadera -y clarividente- es una fotografía no manipulada verdadera como un plano secuencia no manipulado, grabado por miles de imágenes fijas fotografiadas de modo sucesivo por un dispositivo mecánico. De hecho, algunos de los más importantes experimentos fotográficos como el zoopraxiscopio de Eadweard Muybridge, o la cronofotografía de Etienne Jules Marey, consistían en la disposición de varias cámaras fotografiando 
sucesivamente un cuerpo en movimiento, un caballo, un pelícano, un hombre, con el fin de descomponer y comprender cómo se desenvuelve el movimiento.

Esto es precisamente lo que otorga ese grado supremo de confianza en quien revisa las fotografías, o revisa los planos. Y la manipulación tiene sentido, se ejerce sin compasión, en la misma medida en que otorgamos al procedimiento mecánico de grabación un carácter de verdad sin discusión. Como dice Walter Benjamin:

"lo que sigue siendo decisivo en fotografía es la relación del fotógrafo con su técnica. Camille Recht -sigue diciendo- la ha caracterizado con una bonita imagen: "El violinista debe empezar por producir el sonido, tiene que buscarlo, que encontrarlo con la rapidez del rayo; el pianista pulsa la tecla y brota el sonido. El instrumento está a disposición tanto del pintor como del fotógrafo. El dibujo y la coloración del pintor corresponden a la producción del sonido al tocar el violín; como el pianista, el fotógrafo se las tiene que ver con un mecanismo sometido a leyes limitadoras que ni con mucho se imponen con la misma fuerza al violinista"[...]"25

Volver a ver una fotografía, revisar una grabación videográfica, son actos semejantes. La fotografía formal se hace verdadera a través de las otras fotografías que la conforman tanto en la sucesión temporal, como en la sucesión espacial, lo que contribuye a que el montaje fílmico o televisivo instantáneo sea también una forma de confirmación o verificación de los datos representados en cada plano. La composición de planos, cada uno compuesto por cientos de fotogramas en sucesión viene a contribuir, a corroborar y a representar materialmente el criterio de verdad fotográfico que expusimos en el artículo. Una fotografía se verifica por otras, tanto en la sucesión como en la disposición espacial. Pero su verdad depende, en definitiva, de la ausencia de manipulación. De hecho, ante el problema de la veracidad del directo de los astronautas en la Luna, finalmente, Bueno acaba reconociendo que sólo si se conocen los mecanismos que pusieron en marcha todo el acontecimiento podría determinarse la veracidad de tal acontecimiento, y por tanto, la veracidad de las mismas secuencias que lo representan, -entre otras cosas, porque no es posible otro punto de vista audiovisual.

Lo más importante, para no dejarnos llevar por suposiciones metafísicas o por la propia fascinación de los medios, es que la clarividencia no solo es la propiedad de ver a través de cuerpos opacos en directo, sino también la propiedad que permite ver a través de distancias temporales irreversibles, situaciones irrecuperables, como las que traen a nuestros ojos las fotografías formales verdaderas. Esas fotografías tienen el don de la clarividencia temporal, y espacial, de la misma manera que la tiene una grabación videográfica con el paso del tiempo. ¿Por qué la clarividencia solo puede ser espacial? ¿Sólo porque queremos defender el directo como criterio de diferenciación de la televisión? Pero esa suposición es ad hoc. La clarividencia es temporal, de hecho sólo puede ser también temporal porque el directo es prácticamente imposible. $\mathrm{Y}$ al fin y al cabo el falso directo y el diferido suponen

\footnotetext{
${ }^{25}$ Walter Benjamin, Sobre la fotografía, Pretextos, Valencia 2007; pág. 37-38.
} 
la clarividencia temporal. Y si es temporal también, ¿cabe seguir afanándose por defender una televisión formal sólo en la situación del directo, o el falso directo, en lugar de la situación en la que se graba sin cortes ni manipulaciones?

Al fin y al cabo, la clarividencia como tal sólo tendrá lugar cuando aquello que "vemos" esté ocurriendo o haya realmente ocurrido, pues, en todo caso, si se trata de una imagen falsa, manipulada, nunca habría ocurrido, y por tanto nunca hubiera podido ser vista, ni en directo, ni en diferido. Nadie vio a Lenin hablando sólo sin Trotski en aquel mitin. Por otro lado, un mensaje como el que Orson Wells protagonizó emitiendo por la radio la guerra de los mundos, dio lugar a un movimiento de masas, sin que necesariamente lo que ocurría fuera verdadero; incluso se emitía en directo, pero lo que emitía era una adaptación teatral preparada en el estudio de radio. No puede ser lo mismo en absoluto, reproducir una grabación en el reproductor del salón, que ver la misma película a la vez que los cientos de miles que pueden verla en ese mismo momento, independientemente de que haya sido previamente grabada. $Y$ en esto, la televisión es exactamente igual que la radio, salvo por el hecho de que emite señales audiovisuales. Los efectos de una grabación verdadera emitida en diferido no pueden menospreciarse por el hecho de que falte al directo, serán determinantes si aquello de lo que se trata es verdadero e involucra a las personas que lo ven, por ejemplo, una grabación de las torturas en las cárceles de Irak por parte de las tropas "aliadas". El hecho de que se vean en diferido por millones de receptores, aunque se trate de "televisión material", puede ser determinante, o debería serlo, para el futuro político de un George Bush, un Tony Blair, etc. En todo caso, si se hubieran emitido en directo la situación de estos adalides de la libertad no hubiera cambiado. En efecto, la escena en que Tony Blair habla a los periodistas con el gesto severo, justificando la invasión de Irak, mientras resplandecen las lucecitas del árbol de navidad a su espalda, no dejará de ser una infamia por el hecho de que ya no la podamos ver en directo. La grabación seguirá existiendo y será un dato más para las futuras generaciones. La muerte de un padre y un hijo en Palestina, acribillados por soldados judíos, mientras se refugian de los disparos detrás de un barril, no dejará de ser una infamia por el hecho de que no lo podamos ver en directo, ha quedado en la memoria audiovisual y será un dato más para las futuras generaciones (toda la discusión sobre si esta grabación es verdadera recurre a los planteamientos aquí establecidos sobre la verdad: buscar nuevos puntos de vista (otras cámaras grabando), y analizar si se trata de una manipulación o un montaje, pero si es difícil establecerlo aquí, ¿qué podría decirse de acontecimientos como el alunizaje del Apolo XI?).

\section{Fotografía como reliquia}

La fotografía, así como el vídeo grabado sin manipulación, es ante todo una reliquia y, como tal, fundamento gnoseológico de la verdad histórica. La clarividencia de la televisión no depende del directo, sino del hecho de que lo emitido sea verdadero, no haya sido manipulado, no sea, simplemente, una película, a la que también se le podrán aplicar diversas distinciones en función de lo que se esté estudiando, por ejemplo, cuando se estudia la evolución de la 
magistral interpretación de Carmen Maura en el magistral cine de Almodóvar. De hecho, tanto la imagen fija como la imagen grabada en movimiento, se convierte en lo que Bueno ha llamado reliquia perfecta, pero con la peculiaridad de que la reliquia es perfecta sin necesidad de que desaparezcan los sujetos operatorios que las construyeron (tal es el criterio de definición de reliquia perfecta); pero en este caso, basta dejarlas establecidas por el procedimiento de grabación mecánica para que lo sean ${ }^{26}$; no necesitamos, como el fugitivo de La invención de Morel, morir y desaparecer como operarios de la máquina que nos graba dentro de la historia de Faustine.

La historia de Francisco Boix tiene mucho que decirnos en este asunto. Boix, fotógrafo español, soldado republicano y prisionero de los nazis en Mauthausen, fotografió y guardó, mediante una historia heroica y sorprendente, historia que nos dignifica a todos -como no puede ser de otra manera-, los clichés en los que había fotografiado escenas del campo de trabajo, muertos en descomposición enredados en las alambradas, crematorios y altos cargos del nazismo visitando la prisión ${ }^{27}$. Boix fue testigo en al menos dos procesos de Nüremberg y sus fotos fueron presentadas como pruebas para la incriminación de varios de los imputados. Aquellas reliquias fotográficas no necesitaron matar al sujeto operatorio que las realizó (aunque Francisco Boix murió muy pronto, a consecuencia de su estancia en el presidio), las guardó, las reveló y las positivó al terminar la guerra, para ser utilizadas como pruebas en los juicios de Nüremberg. Fueron reliquias perfectas y verdaderas, precisamente porque el sujeto operatorio no las manipuló, sino que simplemente enfocó la cámara, y aprovechó su técnica para dejar testimonio de un acontecimiento histórico. La toma videográfica continua que graba a la niña vietnamita que sale corriendo de un bombardeo de napalm en la guerra de Vietnam tampoco necesita matar al sujeto operatorio para convertirse en una reliquia perfecta porque una vez realizada no se manipula; al igual que aquellas fotografías, quedaron tal como fueron realizadas en su momento. $Y$ cada nuevo positivado repite la misma imagen, salida del mecanismo automático de la disposición de los elementos químicos en la reacción química del revelado, así como cada nueva reposición en televisión repite los mismos acontecimientos grabados en la secuencia.

La fotografía formal y la televisión y el vídeo están destruyendo el presente, dándole profundidad y volumen, desbordándolo constantemente al llenarlo de reliquias de sí mismo que lo convierten en pasado. No hay nada más entrañable que una pareja fotografiándose a sí misma alargando el brazo asiendo la cámara; mirando hacia delante, dejan atrás el tiempo en el que esa misma fotografía sucede y queda inalterablemente involucrada en su presente. Las reliquias así construidas constituyen los verdaderos hechos históricos, hechos fenoménicos pero con la peculiaridad de que han sido fabricados por

\footnotetext{
26 Véase, para el concepto de reliquia perfecta, Gustavo Bueno, "Reliquias y relatos", El Basilisco, número 1, marzo-abril 1978, páginas 5-16; p. 11

${ }^{27}$ Véase el documental de Lorenzo Soler, Francisco Boix, un fotógrafo en el infierno, 2000 (en Internet: http://video.google.com/videoplay?docid=-4585635582953202062\#; Benito Bermejo, Francisco Boix, el fotógrafo de Mauthausen. Fotografías de Francisco Boix y de los archivos capturados a los SS de Mauthausen. RBA, Barcelona 2002. También Wilipedia: http://es.wikipedia.org/wiki/Francisco_Boix.
} 
procedimientos mecánicos, cuando no son manipulados, otorgando a la Historia, por ejemplo, una solidez gnoseológica que no le pueden dar ni las reliquias ni los relatos b-operatorios anteriores al descubrimiento de la fotografía. De modo que la Historia que se realiza a partir del tiempo en el que se vulgariza la técnica fotográfica una vez que fue asumida su patente por el estado francés, no puede ser la misma, precisamente por la peculiaridad de las reliquias y relatos que conforman su campo gnoseológico, frente al tiempo en el que esos descubrimientos técnicos aun no habían tenido lugar. Si las reliquias son la forma de presencia del pasado, la fotografía y la secuencia videográfica formal, o una grabación sonora con la voz de Ortega, por ejemplo, son las reliquias en grado sumo.

Estos hechos presentes, en tanto que fenómenos en su propia entidad fisicalista, son fenómenos peculiares porque, cuando se trata de la fotografía formal, y la secuencia videográfica formal, no van referidos a sujetos operatorios solamente, aunque siempre haya un operario de cámara o un fotógrafo, también van referidos particularmente a la cámara de vídeo o a la cámara fotográfica que impone por así decir su propia lógica y determina el hecho de modo alfa-operatorio, mecánico. Pero son fenómenos en la medida en que ocultan a la vez que muestran la esencia: "Y en Historia [en la fotografía, diríamos nosotros] (así como en algunas otras ciencias etológicas), lo característico es que la ocultación no es sólo pasiva, sino activa, por cuanto los «fenómenos» han sido, muchas veces, fabricados precisamente con la intención de encubrir, de ocultar, de engañar: en realidad, esta intención, como tal (operatoria) sólo podría atribuirse a las ciencias históricas o humanas. El descubrimiento del engaño, por ello, no equivale automáticamente a una revelación de la «esencia», sino a la revelación del «fenómeno verdadero» (beta-operatorio)"28

En el caso de la fotografía, la mayor preocupación es la posibilidad de demostrar que una verdadera fotografía no es sin embargo una fotografía verdadera, esto es, ha sido manipulada; es decir, descubrir el fenómeno verdadero histórico que dio paso a una imagen manipulada, precisamente porque si no es manipulada, la fotografía es una imagen clarividente de ese pasado, una reliquia verdadera. La lucha contra la fotografía del Miliciano muerto en Cerro Murriano de Robert Capa no solo es una lucha contra la manipulación de la imagen fotográfica, sino también una lucha contra lo que esa imagen supone en tanto reliquia clarividente de un acontecimiento histórico que ella contribuye a esclarecer o a ocultar (según se demuestre su carácter verdadero o no), por eso es una discusión claramente viciada por prejuicios ideológicos. En otros casos, la única consecuencia es la retirada de un premio, como le ocurrió a José Luís Rodríguez el año pasado, quien, después de haber recibido el premio Veolia Environment Wildlife Photographer of the Year 2009, por su extraordinaria fotografía "Lobo saltando una cerca", perdió el premio debido a que se la fotografía habría sido manipulada, pues al parecer se trataría de un lobo domesticado. El procedimiento no dejaba de ser verdaderamente interesante: utilizó la técnica de la trampa infrarroja, con lo que

${ }^{28}$ G.Bueno, "Reliquias y relatos", Op. cit., pág. 14 
la fotografía se realizaría por procedimientos mecánicos, sin intervención directa del fotógrafo. Una verdadera fotografía pero, al parecer, fotografía falsa.

\section{Reliquias clarividentes}

Pero las reliquias fotográficas y videográficas no solamente son reliquias históricas. Al estar involucradas en el presente, al destruir el presente a cada instante, sin necesidad de que desaparezca el sujeto operatorio que las realizó, porque una vez hechas no se manipulan (hablamos de la fotografía formal), entonces, estas reliquias están involucradas en el presente histórico de los propios sujetos operatorios que las realizan, y contribuyen a complicar nuestra propia existencia. Son pruebas de cargo en los juicios, informaciones periodísticas, recuerdos personales, fetiches, y obras de arte. Su capacidad para influir causalmente en el presente histórico en el que son realizadas las fotografías o las secuencias videográficas, o las grabaciones de audio, va mucho más allá del directo, o del falso directo, salvo que asumamos una noción no antropológica del tiempo presente, y nos acojamos a una noción de tipo físico o matemático que no nos sirve, porque estamos a escala antropológica, no en el campo de la simultaneidad gnoseológica de la física.

No es el directo, sino el presente histórico aquel en el que las reliquias fotográficas y videográficas pueden adquirir un papel causal más o menos inmediato, pero en todo caso, por su clarividencia temporal y espacial: en la medida en que puedo verme a mí mismo en aquella fotografía que me hicieron al lado del relieve de Nicolai Vavilov en San Petersburgo, en el año 2003, y comparar cómo ha ido mi evolución fisiológica, o personal, o aquella fotografía de Trinidad Jiménez, Zapatero y Tomás Gómez, o la de Aznar y Bush acompañados de Tony Blair en las Azores. Si asumimos la clarividencia como una propiedad de las reliquias fotográficas espacial y temporal, en tanto que son verdaderas, entonces el papel causal de estas reliquias (no solo históricas) en las modulaciones del presente adquiere un significado mucho más complejo y dialéctico que aquel que pretende simplemente atribuir papel formal al directo televisivo, mientras que relega al consumo íntimo (supuestamente irrelevante) del salón de la casa, a todo lo demás, lo grabado y lo fotografiado.

En la medida en que las reliquias y los relatos constituyen la Historia, las fotografías y las secuencias videográficas conforman nuestro presente histórico, más allá del directo "instantáneo", aunque así nos lo quisiera hacer creer la euforia del Gran Hermano. La clarividencia espacial y temporal de la fotografía permite interpretar tanto a las fotografías como a los planos videográficos como una especie de directo antropológico, aunque no instantáneo, porque nos hablan no sólo del "pasado", sino también de nuestro presente histórico. Tan directo, tan presente, tan actual, es la fotografía de Aznar en las Azores como la secuencia en la que Juan Carlos I dice a Chávez "por qué no te callas". No es instantáneo, ciertamente, es diferido, pero sí es presente. Y si lo característico del directo es que puede ser imprevisible, lo característico de las reliquias fotográficas y videográficas es su carácter irrevocable. La repetición de estas imágenes a través del emisor televisivo a todos los potenciales receptores contribuye a confirmar un rumor, a reforzar 
una postura ideológica, a modificar los votos en unas elecciones, a cambiar nuestra praxis, a ahorcar a los reos nazis. Y esa praxis ha sido modelada por esas mismas reliquias que nos hablan de los asuntos en los que estamos involucrados ahora mismo como personas, no sólo nos alimentan el interés por los acontecimientos históricos. No se necesita que lo emitido sea hic et nunc, sino, simplemente, que sea emitido, para jugar un papel causal en nuestra praxis (aunque sea manipulado). El que esté ocurriendo en directo sólo acentúa el grado de veracidad que cabe atribuirle, sobre todo si se trata de una sola toma secuencia, pero no por no ser directo necesariamente dejará de tomarse como verdadero y, por lo tanto, agente causal de nuestras acciones.

\section{Picasso, fotógrafo material}

Los profesionales del fotoperiodismo han tomado la fotografía de Capa, y algunas otras, como norma de su profesión: la búsqueda de la "Fotografía por excelencia". Qué busca el fotógrafo que se representa de modo un tanto mítico esa fotografía total. Por ejemplo los fotoperiodistas que protagonizan la elocuente película de Oliver Stone, Salvador, de 1986 en la que se relatan los trágicos sucesos del asesinato del obispo Serrano. Ni más ni menos, lo que se busca con la fotografía total es la esencia del arte de la fotografía y del cine y de la televisión, la aspiración suprema de la iconosfera en la que tenemos nuestra existencia: la fotografía autoevidente, o la fotografía que contiene en sí misma todos los elementos que la confirman como una fotografía verdadera: que no necesita de otras fotografías para ser confirmada, ni de textos o sonidos que la expliquen. Que se explique por sí misma: que por si misma pueda hablar no sólo de su formalidad fotográfica, sino de su carácter verdadero. Y esto es lo que Capa habría conseguido si su foto no hubiera sido manipulada. El miliciano abatido en la tierra española. La muerte de la República. Que todos los elementos que la integran definan una escena con valor total. Picasso quiso hacer una falsa fotografía verdadera con el Guernica: un cuadro que pretendía ser una fotografía pero pintado, no creado por procedimientos mecánicos, esto es: falsa fotografía. Pero en donde quedara representado el significado de la guerra civil española: la destrucción de España, de la República española. Un cuadro que representa la fotografía total, autoevidente. (La pretensión cubista de incluir en el mismo cuadro distintos puntos de vista apuntaba tal vez en la misma dirección gnoseológica acerca de la determinación de la verdad de la fotografía a través de otros encuadres de la misma escena.) Nadie necesita que se explique cada uno de sus elementos para comprender de un vistazo el horror de la guerra. Insistimos: El Guernica es un fogonazo nocturno, un flash que nos permite ver en el momento de la muerte a la "sagrada familia"... española; un cuadro que sólo podía enardecer al pueblo en armas.

\section{Bibliografía}

Publio López Mondéjar, Historia de la fotografía en España. Fotografía y sociedad desde sus orígenes hasta el siglo XXI, Lunwerg editores, Barcelona 2005. 
Gustavo Bueno Martínez, Televisión: apariencia y verdad, Gedisa ed., Barcelona 2000.

Eugenio Trías, Lo bello y lo siniestro, Ariel, Barcelona 1988.

Manuel Kant, Crítica del juicio, Espasa calpe, Madrid 1989.

Aristóteles, Poética, Bosch, Barcelona 1985.

Fritz Saxl, La vida de las imágenes, Alianza, Madrid 1989.

James Watson, La doble hélice, Alianza, Madrid 2000.

Susan Walter y Morris Bierbrier, Ancient Faces. Mummy Portraits from Roman Egypt, British Museum Press, Londres 1997.

El compromiso de la mirada. Imágenes de la postguerra europea, 1945-1962, Fundación la Caixa, Barcelona 1995.

Tony Hey, Patrick Walters, El universo cuántico, Alianza, Madrid 1989.

Jacques Le Goff, Los intelectuales en la Edad Media, Gedisa, Barcelona 1986.

Capa: cara a cara. Fotografías de Robert Capa sobre la Guerra civil española, Ministerio de educación y cultura, Madrid 1999.

El neorrealismo en la fotografía italiana, Ayuntamiento de Madrid, Madrid 1999. 